\title{
Globalism, global governance and the promotion of security: reflections on Southern Africa
}

\author{
DR THEO NEETHLING \\ Centre for Military Studies, University of Stellenbosch
}

\section{Introduction}

The Charter of the United Nations (UN) was drafted while the devastating effects of World War II were still very much part of the dynamics in international relations. The world's leaders were determined never to let war happen again and had set their minds on the advancement of all peoples. To this end, they ratified arguably the world's most important political document when the Charter was signed in San Francisco in 1945.

No global war has occurred since the Charter was signed. However, humanity has experienced much conflict, suffering and injustice as a result of inter-state and intra-state wars. The division between the Western and Eastern powers with their respective security alliances and institutions also reflected the political-military rivalry in international politics.

In 1989, when the Berlin Wall came down and events in the former Eastern Bloc signalled a new era, the international community sensed that humanity was on the verge of new developments and a changing security agenda. Whereas the need for co-operation in the international community guided the broad vision of the drafters of the Charter of the UN, there is an even wider and deeper realisation of the interdependence of the nations of the world today.

The strongly bipolar structure of international relations during the era of the Cold War has made way for a more multi-polar structure with the emergence of new economic powers. In fact, the movement towards a new world order and the reality of greater economic interdependence in the 'global village' have led to a growing awareness that the world forms an integrated unit. This reality of greater international interdependence has a significant impact on perspectives on national security.

The demands and realities of the new era therefore necessitate a revaluation of what 'national security' means. While the traditional approach to national security contributed to the militarisation of the world, it resulted in an under-emphasis of non-military threats. This also led to a misconception that all threats to and problems of national security could be countered through military action, which resulted in a somewhat distorted view of security, as security management systems were equated with military solutions. In the post-Cold War period socio-economic, political, environmental and other international dimensions have become recognised as part of a broader framework for actions and policies to be carried out in pursuit of a better life in the 1990s. Hence the security problems of today's world are more complex than before. Modern societies are vulnerable to threats or dangers for which there are no military solutions. This includes social problems such as migration, weapon smuggling, human and economic insecurity caused by poverty, food shortages, health risks, national debt crises, and many more. 
The above-mentioned changes calls for certain adjustments in the strategies for international co-operation with specific reference to the institutions and processes of global governance. It calls for leadership that upholds the values that are needed to live together as neighbours, and to preserve a balance between the interests of nation-states and the management of global affairs. In the light thereof, the case for multilateralism has gained special relevance as a result of the need to create forums that can provide leadership in the economic, social, environmental and security fields.

This paper will assess the promotion of global security in the context of globalism and global governance. It will furthermore address the case for regionalism and multilateralism as important elements or components of the contemporary 'global village'. Against this background, it will attend to certain security principles in the current era and reflect upon the need to respond to security challenges and crises in a regional context with specific reference to Southern Africa. South Africa's position in this regard will likewise be discussed.

\section{Towards globalism and a common vision}

Few words are more arbitrarily used today than the term 'global'. Ecology is said to be a 'global' problem. The media is said to be creating a 'global' village. Companies are often stating that they are 'globalising'. Economists talk of 'global' growth or recession.' There is also growing agreement that the international community is increasingly interconnected and that national boundaries are 'less important' than a few decades ago. ${ }^{2}$ 'Interdependence' stands for shorthand for the transnationalisation of the international community - not just as regards events, but also with respect to ideas, institutions and decision-making. ${ }^{3}$

When the UN system was created, nation-states were by far the most prominent elements of the international community. At that time the international community focused its attention largely on preventing a Third World War between nation-states. Thus the establishment of a framework of international or intergovernmental institutions to ensure peace and prosperity was a welcome development in international politics. At that stage nation-states had few rivals, since the vast array of global firms, corporate alliances and non-governmental organisations that has emerged in recent decades was just in the process of development. As such, the world economy was simply not as closely knit together as it is today. ${ }^{4}$

From around 1960 onwards, international politics experienced a change from 'world politics' towards 'global politics'. World politics concerns a notion which might touch upon every corner of the globe, but do not necessarily do so in practice. Global politics, on the other hand, necessarily involves the globe as a totality and therefore global politics must be conceived in holistic terms. For example, World War II did indeed involve every continent of the globe. However, it did not necessarily involve the globe in a holistic manner as the tropical rain forests of Brazil were, presumably, little affected. Around 1960 nuclear weapons and global delivery systems became available to major powers in

\footnotetext{
A. Toffler and H. Toffler, War and Anti-War: Survival at the Dawn of the 21st Century (London, Warner Books, 1993), p. 318.

B. Boutros-Ghali, 'Global Leadership after the Cold War', Foreign Affairs, March-April 1996, p. 87.

M. Gurtov, Global Politics in the Human Interest (London, Lynne Rienner Publications, 1994), p 9.

Ibid., p 3.
} 
significant proportions. The globe became a potential battlefield, not only in terms of targeting, but also in terms of effects, whether direct or indirect. ${ }^{5}$

In other important spheres of the international community essential changes were also taking place. This was signified by the emergence of new economic powers and arrangements, a growth in international travel, a stronger concern with the environment in all its many aspects, the expansion of academic links across the globe, and many more. ${ }^{6}$

Eventually. a sense of internationalism has become a necessary ingredient of sound national politics. Moreover, with the end of the Cold War the international community started to stress the need for a common vision for the way forward in making the transition from the old order and in managing humanity's journey into the twenty-first century - and especially the need for promoting security in its widest sense, as well as for managing economic interdependence.

The end of the Cold War also extended the movement towards democratisation and economic transformation, raising the prospects of a strengthened commitment to the pursuit of common objectives. The world community seemed to be uniting around the idea that there should be a collective responsibility in a range of areas, including security not only in relation to military affairs, but also in economic and social terms with a view to the promotion of sustainable development, the promotion of democracy, equity, human rights and humanitarian action. ${ }^{7}$

In the light of the foregoing, the following global trends or rearrangements characterise the world order in the $1990 \mathrm{~s}^{8}{ }^{8}$

- Structurally, world politics is increasingly multipolar as political and economic power is more widely spread than at any time since the end of World War II.

- Powerful economic and social forces continue to erode the sovereignty and power of the nation-state, as borders have become increasingly porous and have even been 'softened' or rearranged by global economic forces, transboundary environmental problems, and ethnic, religious and cultural ties.

- Unprecedented opportunities are available for economic revival in the light of increased global interdependence in science, technology, trade and investment.

- Military power is growing less salient to national and international security as many other global factors come into play, such as environmental protection, energy resources and needs, economic management and productivity, scientific and technological innovation, and access to information.

- Superpower rivalry in the Third World has been replaced by more cooperative approaches to international security.

Finally, as far as the notion of global governance is concerned, no clear conception exists in this regard. However, some of its characteristics have emerged. Firstly, it is multipolar in the sense that there are many role-players. Secondly, it is

J. Groom, 'The End of the Cold War, Conflict and Global Governance', Strategic Review for Southern Africa XVII(1), May 1996, p 4.

Ibid., p 5.

The Commission on Global Governance, The Report of the Commission on Global Governance: Our Global Neighbourhood (New York, Oxford University Press, 1995), p 1.

M. Gurtov, op cit., pp 12-16. 
multidimentional in that it embraces political, economic, social and cultural issues. Perhaps its most definingcharacteristic is that it focuses on issues that necessarily concern everyone. In a practical sense, global governance does not equate itself with the UN, although the UN machinery is an important part of it. ${ }^{9}$

\section{The new world order and the nature of global security}

The move to a new world order calls for a broader and more holistic framework for security analysis - one in which peace and security are conceptualised in much wider terms and which includes a focus on quality of life, social justice and human rights. It follows that security does not rest on force alone, or even upon the threat of force. ${ }^{10}$ The UN has therefore defined human rights for the international community. Through a series of global conferences it has promoted international consensus on a variety of issues, of which the creation of a safer world is an important one. ${ }^{11}$

In response to globalisation, the notion of 'global humanism' has been created. It combines two approaches. On the one hand a set of humane values is used to examine national politics, ideologies, social forces and institutions everywhere from the particular point of view of the needs and interests of the planet, considered as a human community. An attempt is made to provide political and ethical guidelines that can be applied to evaluate politics in and between all social systems. On the other hand, one finds the approach of political economy. As applied in international politics, political economy focuses on the way certain systems and structures (such as military-industrial complexes) often decisively influence the distribution of wealth and power within and between nations, and therefore the character of national and international security. ${ }^{12}$

'Global humanism' rests on certain beliefs and approaches. It is idealistic in nature and inter alia offers an alternative approach to national and international security as it rejects the inevitability of war, permanent enemies, and permanent crises. Certain values are primary, namely: ${ }^{13}$

- peace - meaning the minimisation of violence and the institutionalisation of non-violent ways to resolve conflict;

- social and economic justice - movement towards equity in reward and opportunity for all;

- political justice - civil liberties guaranteed in law and practice;

- ecological balance - including resource conservation and environmental protection; and

- humane governance - popular participation in, and the accountability of, government.

In view of the above, different notions of security prevail. As the face of global society has changed, so has the nature of giobal security. Among the concepts frequently used are common security, collective security, and comprehensive security. Common security recognises that lasting security will not be achieved until it can be shared by all and unless attained through co-operation. Collective security is based on the idea of

9 J. Groom, op cit., p 17.

10 S.J. Baynham, 'Regional Security in the Third World with Specific Reference to Southern Africa', Strategic Review for Southern Africa XVI(1), March 1994, pp 90-91.

11 B. Boutros-Ghali, op cit., p 87.

12 M. Gurtov, op cit., pp 8-9.

$13 \quad$ Ibid., p 53. 
members of a particular grouping renouncing the use of force among themselves while also pledging to defend others in case of an attack. Comprehensive security emphasises changing the present military-based notion of security through the ideas of co-operation, confidence-building, transparency, gradual disarmament, communication, demobilisation and demilitarisation.

Moreover, a new concept - human security - has also started to receive attention. It is a people-centered approach that is not so much concerned with weapons as with basic human dignity. It includes safety from threats such as hunger, disease and repression, as well as protection from sudden and harmful disruptions in the patterns of daily life. It also recognises that global security extends beyond the physical protection of borders, ruling elites and exclusive state interests. ${ }^{14}$

\section{South Africa's foreign policy and the promotion of security}

In Southern Africa the issue of human security is a burning one. Population growth, mass migrations, hunger, disease, ethno-centric nationalism, small arms proliferation, a rocky road to pluralism, weakly developed civil-military relations, lack of economic growth and others are all major human security concerns or sources of regional instability in this part of the world. ${ }^{15}$ Against this background, the South African White Paper on Intelligence envisages that the country's security policy should go beyond an absence of war to encompass the pursuit of democracy, sustainable economic development and social justice, and that security policy must deal effectively with the broader and more complex questions relating to the vulnerability of society. National security objectives should therefore encompass the basic principles and core values associated with a better quality of life, freedom, social justice, prosperity and development. ${ }^{16}$

Practically speaking, problems in respect of political conflict are not confined to national borders. The conflicts in Rwanda, Somalia, the Democratic Republic of the Congo (DRC) and the former Yugoslavia have all proved that, when a state collapses as a result of internal conflict, serious turmoil can be experienced across an entire region. The South African White Paper on Defence therefore rightfully claims that such factors impact negatively on neighbouring states in the form of a range of non-military threats: environmental destruction; the spread of disease; the burden of refugees; cross-border trafficking in drugs, stolen goods and small arms. ${ }^{17}$

South Africa shares a common destiny with Southern Africa. ${ }^{18}$ Domestic peace and stability will not be achieved within the context of regional instability. The South African Defence Review therefore recognises the concept of common security as a policy framework with many advantages, as it would facilitate the sharing of information and resources, early warning of potential crises, joint problem-solving, the implementation of confidence- and security-building measures to provide for greater transparency in regional military matters, the negotiation of security arrangements, and the resolution of inter-state

The Commission on Global Governance, op cit., pp 80-81.

H. Solomon and J. Cilliers, 'Sources of Southern African Insecurity and the Quest for Regional Integration', in H. Solomon and J. Cilliers (eds), 'Poverty and Peace: Human Security in Southern Africa', IDP Monograph Series 4, May 1996, pp 7-18.

White Paper on Intelligence, WP (H) - October 1994, pp 6-7.

White Paper on Defence, as approved by Parliament on 14 May 1996, 1996, p 22.

South African Defence Review, in Defence in a Democracy, 1 Military Printing Regiment, 1998, p 20. 
conflict through peaceful means. ${ }^{19}$

For leading South African politicians this new approach to defence also relates to the much-debated concept of an African renaissance. On that account, former Deputy Minister of Defence, Mr Ronnie Kasrils remarked that it “... reinforces this renaissance by guaranteeing peace and security, the prerequisites for a successful rebirth and an age of enlightenment". He went on to say that "African states must be able to protect the people, resources and sovereignty of the countries on the continent. Our (the South African) defence force can be among the champions of this renaissance, jointly performing a role as guardians of peace and guarantors of stability, and standard bearers for democracy and progress." 20

In view of the above, South Africa's foreign policy framework provides for a commitment to the following fundamentals: ${ }^{21}$

- The promotion of human rights.

- The promotion of democracy.

- Justice and international law in the conduct of relations between states.

- International peace and internationally agreed-upon mechanisms for the resolution of conflicts.

- The interests of Africa in world affairs.

- Economic development through regional and international co-operation in an interdependent world.

The country places great emphasis on a variety of peaceful methods of conflictresolution and stresses the role of measures such as 'preventive diplomacy', 'peace building' and 'peace making'. The role of the military is seen as supportive of the abovementioned diplomatic and political objectives, and as a measure that is utilised in support of the defined political objectives. In this regard, South Africa is committed to co-operate with regional partners, especially those within the Southern African Development Community (SADC) in enhancing its capacity to participate in peace missions. ${ }^{22}$

In the light of the above, it appears that South Africa envisages for itself an inevitable concomitant responsibility to participate in regional and sub-regional conflictresolution and co-operative security in a responsible manner, viz. through involvement in peace missions. In this sense, the case for multilateralism and regionalism is of particular relevance for the positioning of South Africa on the subcontinent.

However, it is noteworthy that the South African outlook on the notion of globalisation is rather skeptically perceived. It is strongly regarded as a phase of transition of international to transnational world economy, and a process aimed at transforming the entire world into a global market, operating according to a universal set of rules. $^{23}$ In view of this, it is believed that globalisation is driven by international

Ibid., pp 34-35.

R. Kasrils, 'Guns, Butter, Peace and Security', Sunday Times, 14 September 1997, p 26.

White paper on South African Participation in International Peace Missions, as approved by Cabinet on 21 October 1998, p 20.

Ibid., p 8.

23 A. du Plessis, 'Revisiting South Africa's National Interest in An Era of Change and Transition: Theoretical Considerations and Practical Manifestations', Strategic Review for Southern Africa XIX(2), November 1997, p 90. 
economic factors and the advances in science and technology. The underlying foundation is the emergence of a global market represented by the movement of capital, goods and services to all parts of the world, unrestrained by national boundaries or differences in political systems. ${ }^{24}$

Furthermore, globalisation is perceived as a process that inevitably impacts on the sovereignty of states, with states losing some of their sovereignty to an evolving system of international governance. Moreover, this reduction of sovereignty is not evenly spread among the countries of the world but varies according to the economic strength of the various countries. ${ }^{25}$ Accordingly, it is believed that South Africa has to respond to the challenge of globalisation by means of: ${ }^{26}$

- ensuring that the country integrates itself with the world community "....as the country cannot exist outside the context of and contrary to the tendencies which characterise the evolution of human society";

- determining the ways by which the country can impact on the process to advance the interests of its broad masses;

- fighting to a loss of sovereignty especially on the part of Third World countries by strengthening their collective and institutionalised capacity to influence the decisions that will emerge from the system of international governance; and

- engaging in efforts with a view to creating cohesion among the countries of the Third World in order to effectively use their collective strength to bargain with the major powers.

From a South African viewpoint multilateralism provides the basis for the development of strategic alliances and the strengthening of solidarity amongst the developing countries of the South. The country is therefore committed to the development and strengthening of multilateral institutions and conventions, but then as a means to address the concerns of the 'powerless' Third World in the new world order. At the same time it is clear that the South African agenda to forge links and establish alliances with the rest of the continent is a manifestation of efforts in relation to the promotion of common security, which might be regarded as a product of the process of globalisation. It is furthermore strongly inspired by and rooted in the vision of an African Renaissance which inter alia includes the mobilisation of the people of Africa to assume responsibility for their own destiny. ${ }^{28}$

\section{The case for multilateralism and regionalism}

In the international community with its nation-states lie the various manifestations of regionalism. In his 1992 report, An Agenda for Peace, former UN Secretary-General, Dr Boutros-Ghali, referred to a tendency in which regional and continental associations of states are evolving ways of deepening co-operation. ${ }^{29}$

N. Mandela, 'Presidential Report - 50th National Conference of the ANC' , Internet site http:www.anc.org.za/ancdocs/history/conf/conference50/presaddress.html, 19 January 1998, p 42.

Ibid., p 43.

Ibid., pp 43-44,

A. du Plessis, op cit., pp 93-94.

Ibid., p 90.

B. Boutros-Ghali, An Agenda for Peace (New York, UN Department of Public Information, 1992), p 6.
} 
Organisations for regional co-operation and co-ordination of varying capacity cover most of the world, and regionalism remains a strong impulse throughout the world. In fact, it is increasingly recognised that these organisations can help to overcome historic rivalries and tensions, foster democratic processes, enhance the collective value of small and fragmented markets in the creation of trade, help develop shared infrastructure, and tackle common environmental and social problems.

The case for regionalism is also relevant in the context of regional insecurities and the contemporary profile of armed conflict. Suffice it to say that while the threat of conventional inter-state war has been reduced, the potential of regional instability has increased as a result of the fact that many of today's conflicts are within states rather than between states. In parts of Africa, conflicts have escalated into cases of brutal civil wars,

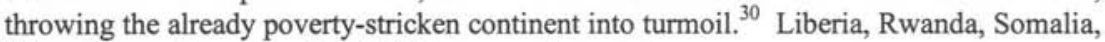
Sierra Leone, Angola and the DRC are cases in point.

As nation-states are often compelled to act jointly, the phenomenon of regionalism cannot be separated from global institutions. Affecting each other, these institutions are linked in a dynamic process of interaction as they have the potential to complement and contribute to global governance. ${ }^{31}$ The concept of global governance accordingly relates to a process through which conflicting or diverse interests may be accommodated and cooperative action may be taken. The underlying principle in this respect is that there is no alternative to working together and using collective power to create a better world. ${ }^{32}$

If a movement to durable peace is to begin, the starting point must be the creation of incentives for nation-states to avoid war in their political conflicts. Ideally, the goal is disarmament within a system of global security. In the process, what must be constructed is what Karl Deutch and his associates called 'a sense of community', meaning that its members do not target each other in a military sense, because their problems can and must be solved through processes of peaceful change and without resorting to large-scale physical force. ${ }^{33}$

However, many leaders in the international community pay lipservice to the 'peaceful settlement of disputes' but frequently resort to military means or war to resolve conflict. What is often needed is a shared perception among leaders that international order is in every society's best interest, and that maximising arguments does not ensure real security or deter threats to it. So, unless states and their leaders have strong confidence in alternative means of protecting their legitimate security interests, they will not agree to steps toward disarmament, nor will they step forward to render support to peace missions, all of which are to a large extent built on mutual trust. ${ }^{34}$

\footnotetext{
30 F. Olonisakin, 'African Homemade Peacekeeping Initiatives', Armed Forces and Society 23(3), Spring 1997, p 350.

31 The Commission on Global Governance, op cit., pp 286-287.

$32 \quad$ Ibid., p 2.

33 K. Deutsch, (et al), Political Community and the North Atlantic Area (New York, Greenwood Press, 1957), p 5.

M. Gurtov, op cit, p 209.
} 


\section{Towards global governance in Southern Africa}

In Southern Africa, the debates on security issues have focused on issues of common security, disarmament and the peaceful resolution of conflict which is based on the idea of the interdependence of nation-states and a clear sense of common destiny. This is based on the realisation that many problems in the regional context transcend national borders and that states are not in a position to protect their citizens unilaterally. The relevant states therefore share an interest in joint survival as they realise the need to organise their security policies in conjunction with one another. These policies are most effective when they are formalised. ${ }^{35}$ In this regard, the states of Southern Africa have opted to use SADC as the appropriate vehicle to address the issue of co-operative security.

Although the promotion of multilateralism and regional co-operation may be a slow process, collective regional security, in which multilateral arrangements would include non-military concerns, has largely dominated at a rhetorical level in Southern Africa thus far. Practically speaking, this relates to the situation that proper structures and a politicalmilitary capacity to satisfactorily deal with peacekeeping and conflict-resolution have not materialised as yet. After creating the SADC Organ for Defence, Politics and Security in June 1996 as a result of a strong emphasis on political and diplomatic mechanisms for securing the region, little progress was recorded in terms of decisions pertaining to the finer details of the structures and institutions of the Organ. ${ }^{36}$ In fact, the Organ, which was established to deal with issues relating to regional inter-state defence and security with Zimbabwean President, Robert Mugabe, as its first annually rotating chairperson, has to date not been formally infrọduced into the 1992 SADC treaty. At the same time, the Organ is mandated to furiction independently and at summit level in parallel with SADC, whose major focus was constructed as being on economic and developmental cooperation among member śtates. ${ }^{37}$

It is also of significance that the Inter State Defence and Security Committee (ISDSC), which is supposed to operate under the guidance of the Organ at a more 'bureaucratic' level, is already 'up and running', deepening and strengthening ties between member countries and constantly evolving new ways of security co-operation. ${ }^{38}$ Not only has the ISDSC started with combined planning, ${ }^{39}$ but at a practical level it has been instrumental in two multinational battalion level peacekeeping exercises on Southern African soil. ${ }^{40}$

One possible explanation in respect of the above-mentioned deficiency within SADC could relate to the supposition that'multilateral co-operation is likely and more easily achievable among partners with a common system of values and more or less the same level of development - and this seems to be lacking among members of SADC. With the exception of South Africa and possibly Zimbabwe to some extent, the economies of Southern African states are small and underdeveloped. Progress towards

H. Solomon and J. Cilliers, op cit., p 6.

See M. van Aardt, 'The Emerging Security Framework in Southern Africa: Regime or Community' , Strategic Review for Southern Africa XIX(1), May 1997, pp 1-30, for a detailed discussion.

I. Powell, 'High Noon in Mauritius', Mail \& Guardian, 11 to 17 September 1998, p 30. Ibid., pp 13-18.

G. Thiart, 'Training for Peace', Salut 3(3), March 1996, p 26.

Southern African Development Community, Exercise Blue Crane South Africa 7-30 April 1999, Info Booklet for Military Attachés, 1999, pp 3-4. 
reducing the region's economic imbalances and to mobilise regional development resources fully remains a serious challenge. ${ }^{41}$

Another problem area seems to relate to a continuing row between South Africa and Zimbabwe over control of regional security matters, with particular reference as to how Southern African states should jointly respond to civil conflicts. According to reports, Zimbabwe doesn't want the regional security decision-making apparatus to become susceptible to the blandishments of regional human rights groups. On the other hand, South Africa favours an approach that security issues should be firmly subordinate to politically accountable decision-making. As such, these viewpoints concern fundamentally different views of how security should be managed in the region. ${ }^{42}$

In recent years SADC's Organ for Politics, Defence and Security has been in the middle of what was described in the media as a major rift between President Mugabe and former President Mandela over armed intervention in the DRC. In short, this relates to an attempt by a coalition of states under the leadership of Zimbabwe - who chairs the Organ - to rescue the regime of Congolese President Laurent Kabila as anti-government rebels started a march to the capital Kinshasa in August $1998 .^{43}$ The point in question is indicative of an uncomfortable situation in which it is difficult to establish who is actually in charge of decisions pertaining to regional security issues and crises: South Africa as the chairperson of SADC, or Zimbabwe in the capacity as chairperson of the Organ.

Concerns have also be raised about a militaristic ethos which pervades the conflict resolution strategies adopted by some of the other powers in Southern Africa, with special reference to the involvement of Zimbabwe, Namibia and Angola in the DRC. Observers claim that the foreign policy paradigms of these countries have shown little support for conflict resolution (and peace missions) as longer-term, politico-diplomatic strategies and attempts to secure lasting peace and stability. In fact, it has been pointed out that there is a clear disjuncture between the foreign policy paradigms of the above-mentioned countries on the one hand, and those of South Africa, Botswana, Mozambique and Tanzania on the other. ${ }^{45}$

While progress with multilateralism in Southern Africa has been relatively slow thus far, bilateral security arrangements on a host of issues of mutual interest have been flourishing. From a South African viewpoint, bilateral agreements concerning defence co-operation between South Africa and its neighbouring states Namibia, Mozambique and Zimbabwe have been concluded since $1994 .^{46}$

What needs to be stressed is that domestic enhancement of personal and collective

\footnotetext{
41 H. Anyidoho, 'Prospects for Co-operation in Peacekeeping in Africa', in J. Cilliers and G. Mills (eds), Peacekeeping in Africa (Halfway House, Institute for Defence Policy and South African Institute of International Affairs, 1995), pp 111-112. Mail \& Guardian Correspondents, 'The Last Days of Laurent Kabila?', Mail \& Guardian, 21 to 27 . August 1998, p 5 . Paper delivered at a joint conference by the Institute for Security Studies and the SA Institute of International Affairs, Jan Smuts House, University of the Witwatersrand, 25 March 1999, p 15. Ibid., p 26.

Information obtained from the South African Department of Foreign Affairs.
} 
well-being, while improving human rights in the fullest sense, strengthens a leadership's ability and willingness to deal positively with great crises. ${ }^{47}$ To this end, progress towards a shared democratic system of values among the various constituent members of SADC, coupled with sustainable economic growth, are clearly the buildingblocks for greater regional, national and individual security in Southern Africa. ${ }^{48}$

In addition, the strong appeal of Mr Nelson Mandela to members of SADC at the organisation's 1997 Summit to attend to issues of human rights and democratic principles, underpins the very essence of successfully dealing with security issues on a multilateral and regional basis - that is, unless there is security at home, there cannot be a lasting security agenda on a broader level. In this regard, Mr Mandela argued that SADC was committed to the principle of respect for the sovereignty of member-states and noninterference, but that it could not allow this principle to 'override the organisation' and higher principles of respect for democracy, human rights and good governance enshrined in the SADC treaty. He urged member-states that if SADC were to envisage credibility for itself as an organisation genuinely committed to these principles, it could not allow any sector of the organisation to violate them - with apparent reference to political developments in Zambia and Swaziland prior the Summit. ${ }^{49}$

In the context of the above the near future of Southern Africa looks rather clouded by the conflict in the DRC. In Angola - where the UN has withdrawn its observer mission - the situation is one of renewed war where UNITA appears to be in a position to threaten Luanda itself. In Zimbabwe internal unrest has given account of substantial political dissatisfaction with the Mugabe government and has been suppressed with military force early in 1998. In Lesotho the process of finding a lasting political solution remains a serious challenge after peace has been restored by the combined South AfricanBotswana military force in September 1998. In April 1999, the Comores, which effectively forms part of the Southern African community, experienced a military coup d' état. Thus the region clearly suffers from instability and a lack of democratic political values in certain cases.

This has thrown up a number of problems and has produced leadership tensions and disagreement over modalities for security cooperation in Southern Africa. Unfortunately, for some leaders it might be a case of too obvious a programme to facilitate democratisation and elections in another country may backfire on those leaders who themselves face criticism for a perceived increase in intolerance and authoritarianism. ${ }^{50}$ In this context it is important to note that, like African politics in general, foreign policy and national security strategy in Africa, are imbued with flexibility and personalisation. They tend to be associated with regimes, groups, or individual leaders more than nations as a whole. This emphasis on individuals or particular group interests means that leadership at any given time are an important part of African regional security systems, and that a change of leadership sometimes bring a fundamental change in foreign policy, national security strategy and regional security co-operation. ${ }^{51}$

\footnotetext{
$\overline{47}$ M. Gurtov, op cit., p 196.

48 H. Solomon and J. Cilliers, op cit., p 26.

49 Anon, 'Mandela Blasts States on Rights Issue', Pretoria News, 9 September 1997, p 2.

so M. Malan and J. Cilliers, 'SADC Organ on Politics, Defence and Security: Future Development', ISS Papers 19, March 1997, p 1.

51 D. Henk and S. Mertz, 'The United States and the Transformation of African Security: The African Crisis Response Force Initiative and Beyond', Strategic Studies Institute, US Army War College, 5 December 1997, p v.
} 
The above-mentioned obstacles in the Southern Africa region do not imply insurmountable barriers in the quest towards co-operation measures concerning security issues - although some observers claim that the deadlock around the operation of the SADC Organ needs to be resolved as soon as possible if SADC is to survive as a regional institution. $^{52}$ Whatever the case, it does imply prudence and it tempers unrealistic expectations as regards the capacity and collective political will of SADC to be instrumental in shaping the security agenda in the region.

\section{Principles of security in a new era}

In the context of globalism, it is advocated that all people, no less than all states, have a right to a secure existence, and all states have an obligation to protect those rights. Within this framework the Commission on Global Governance suggests that the following be used as norms for security policies in the new era: ${ }^{53}$

- The primary goals of global security should be to prevent conflict and war.

- Global security should be promoted by eliminating the economic, social, environmental, political and military conditions that generate threats to the security of people and the planet, and by anticipating and managing crises before they escalate into armed conflict.

- Military force should not be regarded as a legitimate political instrument, except in self-defence or under the auspices of the UN.

- The development of military capabilities beyond that required for national defence and support of the UN poses a potential threat to human security.

- Weapons of mass destruction are not legitimate instruments of national defence.

- The production and trade in arms should be controlled by the international community.

Analysts accordingly rightly argue that regional security in Southern Africa will be inter alia enhanced through disarmament. An arms build-up inevitably deepens insecurity and anxiety, while also increasing the possibility that conflicts which may potentially be resolved peacefully, deteriorate into armed conflict. ${ }^{54}$ Although somewhat idealistic, embracing these norms in Africa and Southern Africa in particular would go a long way towards securing states against the threat of war, while also finding ways to safeguard people against brutilisation and ensuring the integrity of systems on which many depend to make their daily living.

In the spirit of globalism it is today commonly believed that the international community and its various members, have an obligation to take action in situations where the security of people is imperilled. Several bodies and institutions within and outside the UN play a role in providing security. The security of people - or human security - is enhanced when humanitarian agencies carry out action not only to provide relief, but also to ensure a better environment for victims of conflict or other natural disasters.

A trend over the last few years has therefore been a rise in the number of UN Security Council resolutions that link peacekeeping or enforcement to the provision of

\footnotetext{
52 A. van Nieuwkerk, 'Implications for South Africa's Foreign Policy Beyond the Lesotho Crisis' , ACCORD Occasional Paper, 3/99, p 3.

53 The Commission on Global Governance, op cit., pp 84-85.

$54 \quad$ H. Solomon and J. Cilliers, op cit., p 6.
} 
humanitarian assistance. As regards peacekeeping in Africa, Security Council resolutions on Somalia, Rwanda and Liberia underscored the linkage between military and political objectives, and humanitarian ones. ${ }^{55}$

What seems to be important, is that values upheld by the international community have to be reinforced by the regulatory framework of the regional institutions. As such it calls for concerted efforts to improve co-ordination of policy in the interest of achieving more stable conditions in the various regions of the world. With respect to SADC, it would go a long way if the member-states could develop a set of broad principles for responsibilities to preserve global security. They should also work out clear means to respond appropriately and speedily to threats to peace in co-operation with the UN and the Organisation of African Unity. It is imperative to develop such principles so as to avoid a haphazard, reactive response and decisions implemented hurriedly in reaction to unforeseen crises or as a result of pressure from the external environment.

In the case of inter-state conflict, clear-cut aggression is often easy to define. However, such situations are rather rare today. Much more difficult is the right or even the obligation to act in a purely internal context, as the international community or regional groupings are for obvious reasons not in a position to engage or interfere in any country's domestic affairs in unqualified terms.

However, threats to human security may constitute threats to international or regional peace and security. In Somalia, for example, there was no government to exercise sovereign functions, while in the case of Rwanda, UN intervention was favoured by the Rwandans. ${ }^{56}$ Therefore, one key question that needs to be considered, is: Given the sustained importance of the principles of sovereignty and non-interference in internal affairs, when should a situation in an African or Southern African state be considered to have deteriorated to such an extent that the security of people has been violated to the point that it requires international and/or regional response on humanitarian grounds?

Multilateral intervention will always be done on a case-by-case basis, but the judgement itself must be exercised within a circumscribed framework to which all parties have agreed. The challenge is to find an acceptable basis for humanitarian action that respects the dignity and independence of states without sanctioning the misuse of sovereign rights to violate the security of people within the borders of a nation-state.

It also seems to be imperative to cultivate a regional environment in which the use of force remains the last possible means of resolving disputes, especially when action is undertaken on the basis of humanitarian considerations. From a moral and practical viewpoint, an approach that elevates persuasion, conciliation and arbitration above the use of force, and non-violent coercion above the use of force, should be favoured. The challenge worldwide is to establish an acceptable basis for humanitarian action that respects the dignity and independence of states without sanctioning the misuse of sovereign rights to violate the security of people within a state's borders. ${ }^{57}$

The Commission on Global Governance, op cit., pp 86-87.

Ibid., p 89.

Ibid., p 93.
} 


\section{Concluding remarks}

It could be stated that, freed from the earlier tensions of the Cold War, the world's nations currently have more favourable conditions for working together. The need for cooperation among them has also increased, as they have become more interdependent in many respects. At the same time, new sources of instability and conflict - economic, ecological, social, humanitarian - have opened the way for new approaches to security that call for collective action.

The improvement of global security in its many facets is for obvious reasons a prime consideration of the international community and its regional institutions. The world has not been involved in major warfare since World War II, but conflicts and violence have not diminished. In particular, there has been a rise in strife within states, and conditions in Africa are especially relevant in this respect. Some of these problems have resulted in large-scale suffering and gross abuses of human rights, and have generated clear demands for external intervention. It is therefore appropriate that the international community and its regional groupings should adopt an effective strategy to deal with threats to security in the broadest sense.

There is currently evidence of a worldwide concern over the threats to stability that could arise from non-military factors, and Africa and Southern Africa cannot afford to be left behind - especially since Africa is the continent most plagued by conflict. The permission granted in September 1997 to the DRC to become a member of SADC has already proved to add a new dimension to the regional organisation's dealings with security issues in the light of that country's geo-political position in Africa. SADC's concern with security should therefore extend to the considerations that should govern regional or sub-regional action, whether preventive diplomacy or coercive action in cooperation with the $\mathrm{UN}$, to deal with conflicts within its members that may trigger wider involvement on humanitarian grounds. With internal conflicts prompting calls for intervention, clear guidelines are desirable so that such action be both effective and consistent. The principal challenge all over the world is to mobilise political will towards multilateral action. Attitudes must be fostered that enable enduring collaborative reaction to global challenges.

A crucial factor in the effectiveness of international or regional institutions is their perceived legitimacy. This is linked to participation and transparency in their decision-making processes. Effectiveness also depends on how well institutions are financed and staffed. In addition, a shared democratic system of values among the various constituent members, coupled with sustainable economic growth, usually form the buildingblocks for sound multilateral co-operation - matters which are still of concern in the Southern African context.

Finally, although SADC appears to be caught in a few problems, there is a number of encouraging signs in Southern Africa pertaining to the development of a more appropriate regional security framework. SADC is perhaps the most active sub-regional organisation in Africa and, of all the contributions made by SADC, the greatest has probably been the forging of a sense of a common destiny and a regional identity in Southern Africa. In view of this, SADC members have already started to consider issues of common security, disarmament and the peaceful resolution of conflict. Even if rhetoric is still the real substance of regionalism in Southern Africa and in spite of different views of how regional security should be managed, this does not imply that SADC, with its 
proclaimed aim to invoke the spirit of regional multilateralism, has not started to make its own contribution towards enabling enduring collaborative solutions. At the same time, if SADC is to play a significant role in the promotion of security, in Southern Africa, it would seem that the leaders of the region should encourage and even revitalise this process as the region enters the new millenium. 